\title{
Analysis of the co-seismic responses of the fluid well pattern system in Jiangsu Province to the Wenchuan and Tohoku earthquakes*
}

\author{
Jiangrong Zheng ${ }^{1, \star}$ Haolin Jiang ${ }^{1}$ and Zhengran $\mathrm{He}^{2}$ \\ ${ }^{1}$ Earthquake Administration of Jiangsu Province, Nanjing 210014, China \\ ${ }^{2}$ School of Information Science and Engineering, Southeast University, Nanjing 210049, China
}

\begin{abstract}
This thesis discusses the earthquake reflecting ability of the observation well pattern system of Jiangsu Province, China, which has been digitally renovated, and probes into the cause of the major differences in the earthquake reflecting abilities of well holes at different measurement points. This is achieved through the analysis of the co-seismic responses to the Wenchuan $\left(2008 ; M_{\mathrm{S}} 8.0\right.$, China) and Tohoku $\left(2011 ; M_{\mathrm{S}} 9.0\right.$, Japan) earthquakes. We found that the co-seismic response of water level from regional well holes in Jiangsu Province was stronger than that of water temperature. The water-level co-seismic response follows a consistent law and is closely related to the earthquake magnitude. The co-seismic response of water temperature strongly varied among well points, and was more often manifested as a slow restorative change. The co-seismic responses also varied based on tectonic elements. The response in central and northern Jiangsu was weaker than that of southern Jiangsu, possibly due to the thicker loess cover layer in central Jiangsu which makes it less effective at capturing the micro-changes of stress-strain states relative to the hilly land in the south. The more complicated geological structure in southern Jiangsu makes it contribute to greater changes in the state of underground water after a minor disturbance.
\end{abstract}

Key words: fluid well pattern system; $2008 M_{\mathrm{S}} 8.0$ Wenchuan earthquake; $2011 M_{\mathrm{S}}$ 9.0 Tohoku earthquake; features of co-seismic responses

CLC number: P315.72 3 Document code: A

\section{Introduction}

The co-seismic water-level oscillation of distant and violent earthquakes was discovered in the record of a deep well in Italy as early as 1899. Since then, a significant amount of research has been conducted on this topic. Blanchand and Byerly (1935) put forward a concise theory on how water-level fluctuated in response to reflected seismic waves. Rexin et al. (1962) confirmed the long-cycle response of water wells. As the most active medium in the Earth's crust, underground fluids are used to monitor water-level and water-temperature changes of pressure-bearing wells as a seismic precur-

\footnotetext{
* Received 18 February 2012; accepted in revised form 2 June 2012; published 10 June 2012.

+ Corresponding author. e-mail: jsdzjzjr@126.com

(C) The Seismological Society of China, Institute of Geophysics, China Earthquake Administration, and Springer-Verlag Berlin Heidelberg 2012
}

sor; this not only reflects the strained condition of the water-bearing stratum during the earthquake-free period (e.g., solid tide response), but also shows a clear co-seismic response to distant and violent earthquakes. Through research on this topic, we can reveal the response of the medium of water-bearing stratum under the impact of seismic waves to stress-strain, promote research into the movement of underground water under the impact of regional tectonic stress, improve our understanding of the geological and the hydro-geological conditions in the well region, and promote our recognition and research of the fluid precursors in the process of earthquake preparation (Che, 1990; Zhang et al., 2000; Huang et al., 2000; Zhang et al., 1991). In recent decade, the co-seismic effect phenomenon of national underground fluid observation wells caused by several large earthquakes has aroused the attention of many scholars, and has become a hot area of research. Many 
studies have been carried out on this phenomenon $(\mathrm{Fu}$ et al., 2007; Liu, 2003; Gao et al., 2006; Yang et al., 2007; Liao et al., 2008; Gu et al., 2010; Yin et al., 2009).

This thesis arranges and collects the observation data of two observation items (water level and water temperature) from 10 wells in the digitized observation well pattern system of underground fluids in Jiangsu. We have used this information to study and analyze the changes in co-seismic features and response of water level and water temperature to two disatrous earthquakes $\left(2008 M_{\mathrm{S}} 8.0\right.$ Wenchuan, China, and $2011 M_{\mathrm{S}} 9.0$ Tohoku, Japan). The results suggest that a general law can be applied to understand the co-seismic response of water level and water temperature in observation wells. We discuss the possible cause of the major differences in the response strengths of the fluid observation well pattern system to distant and disastrous earthquakes, which is very valuable as a reference for enhancing the monitoring ability of the underground fluid observation well pattern system of Jiangsu and the subsequent renovations of well holes.

\section{Background on the regional ge- ological structure and overview of the fluid observation well pat- tern system}

The geological structure in Jiangsu Province is dominated by two tectonic elements, the North China fault block region and Lower Yangtze fault block region, with the Tancheng-Lujiang and Huaiyin-Xiangshuikou fault zones as the boundary. The fault structure in the region is highly developed, which can, according to the direction of the fault, be divided into four groups including NE, NW, NNE and near E-W, of which the NE faults dominate in quantity. Large-scale active faults in the regions include the Tancheng-Lujiang fault zone, the Huaiyin-Xiangshuikou fault zone, the JiangshanShaoxing fault zone, the Mufushan-Jiaoshan fault and the Maoshan fault.

Most of the observation points for water level and water temperature in Jiangsu Province are located in active fault zones (including epicental distribution zones and geothermal abnormal zones) and just adjacent to them. In addition, by considering that Jiangsu Province is made up by a vast plain, well-developed loose deposit$\mathrm{s}$, with most underground water being interstitial and that karst water and bed-rock crevice water is scarce, and by also considering the characteristics of the rocks of the observation stratum, we have conducted an overall observation arrangement for different regions according to the well-formation structure and depth, the precision of the solid tide record, earthquake-reflecting efficiency and the post-earthquake effect. Through the digitized renovation in the 9 th five-year plan and the 10th five-year plan periods, the seismo-tectonic conditions, observation environment, the instruments and equipment of these observation well points can meet the demand for earthquake monitoring and forecast. The distribution of the regional active fault zones and fluid well holes are presented in Figure 1a and the basic well hole parameters are presented in Table 1.

Jiangsu Province now has 10 digitized fluid observation wells for observing water level and geotherm. In addition, we can also monitor flow, air temperature, air pressure and precipitation. The LN-3 or LN-3A digital limnimeter are used to measure water level and the SZW-1A digital gauge is used to measure water temperature. In terms of the long-term observation of instruments, some stations (points) have a high observation precision of water level and water temperature in spite of the transient absence of recording caused by the failure of instruments or lightning strikes. Their annual rate of continuation reaches $99 \%$. Solid tide records are both clear and complete. The mechanistic features of the seismic records for distant and violent earthquakes are clear. There is a typical response image. However, the observation effect and precision of some stations (points) are poor, they cannot properly reflect changes in underground fluids.

Based on the $M_{\mathrm{S}} 8.0$ earthquake that occurred in Wenchuan approximately $1300 \mathrm{~km}-1500 \mathrm{~km}$ from Jiangsu Province on May 12, 2008, and the $M_{\mathrm{S}} 9.0$ earthquake that occurred in Japan approximately $\sim 2400$ km-2 600 km from Jiangsu Province on March 11, 2011 (Figure 1b), we analyze the co-seismic response characteristics of 10 digitized fluid observation wells in Jiangsu Province, and then discuss the earthquake reflecting ability of the well holes of different structural units at different positions.

\section{Seismic response features of wa- ter level and water temperature}

3.1 Seismically induced changes in water level and temperature by the $2008 M_{\mathrm{S}} 8.0$ Wenchuan earthquake

Figure 2 indicates that eight of the 10 fluid observation wells in Jiangsu Province had unusual co-seismic responses on the day of the $M_{\mathrm{S}} 8.0$ Wenchuan earth- 


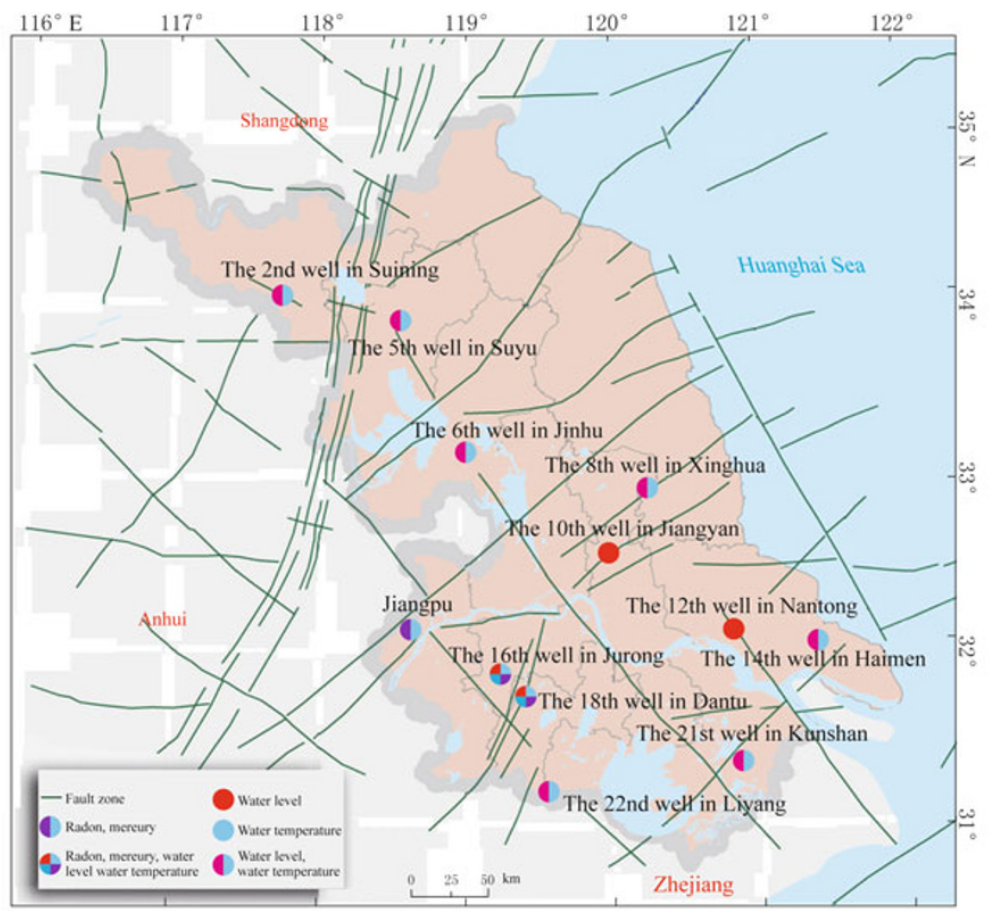

(a)

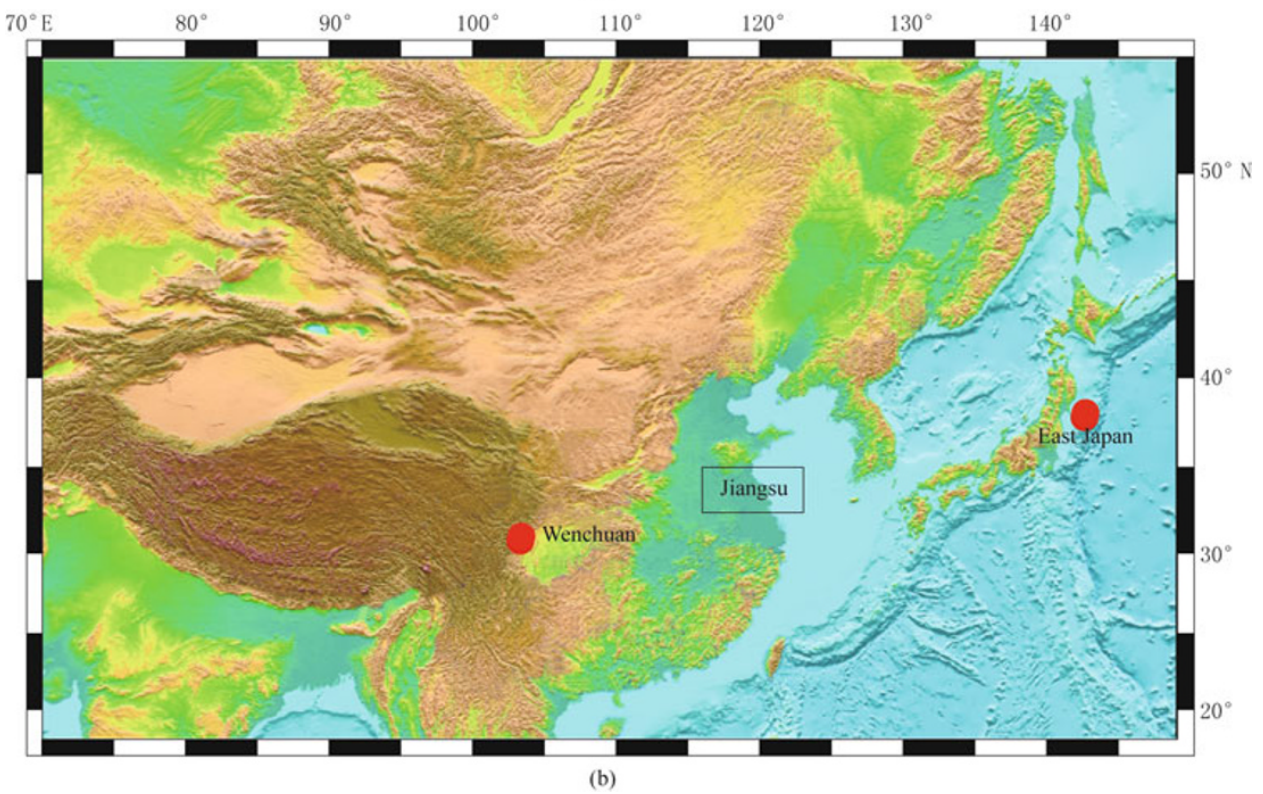

Figure 1 Distribution of the station networks of seismic precursors in Jiangsu Province (a); Relative location of the well holes in Jiangsu with respect to $M_{\mathrm{S}} 8.0$ earthquake in Wenchuan, China, and $M_{\mathrm{S}} 9.0$ earthquake in Tohoku, Japan (b).

quake. The blue curve shows the water temperature record from the deep level observation wells and the black curve shows the water level record from the same wells. Table 2 gives the major co-seismic response parameters, water level and water temperature, during and after the earthquakes.

By analyzing Figure 2 and Table 2, we find a large difference between the co-seismic response of water level and water temperature at the same well hole and the same observation item at different well holes. The waterlevel response can be classified into three types: pulse, sudden change, and pulse trend. In the pulse type, after a rapid rise (or fall) continues for several minutes to half an hour, the observation value is restored to 
the normal dynamic value, with quite different vibration amplitudes among well holes. For example, in Suining well 02 and Liyang well 22, the water seismic value arrived four minutes after the earthquake with a periodic fall-periodic rise (or periodic rise-periodic fall) change with an amplitude over $1 \mathrm{~m}$. This condition restored to the normal state after persisting for half an hour. Only tiny pulses were recorded in Jinhu well 06, Xinghua well 08 and Nantong well 12. There was no suppression of the form of the normal solid tide change. The second type of response is sudden change. The observation value during (after) the earthquake jumps suddenly, with a smaller range than that of the pulse type. Post-earthquake, restoration to the normal pre-earthquake dynamic

Table 1 Basic parameters of the digitized observation points for water level and water temperature in Jiangsu Province

\begin{tabular}{|c|c|c|c|c|c|c|}
\hline $\begin{array}{l}\text { Serial } \\
\text { No. }\end{array}$ & $\begin{array}{l}\text { Station } \\
\text { name }\end{array}$ & $\begin{array}{l}\text { Tectonic } \\
\text { parts }\end{array}$ & $\begin{array}{c}\text { Lithology of } \\
\text { observation stratum }\end{array}$ & $\begin{array}{l}\text { Elevation } \\
\qquad / \mathrm{m}\end{array}$ & $\begin{array}{c}\text { Well } \\
\operatorname{depth} / \mathrm{m}\end{array}$ & $\begin{array}{l}\text { Type of under- } \\
\text { ground water }\end{array}$ \\
\hline 1 & $\begin{array}{l}\text { Suining } \\
\text { well } 02\end{array}$ & $\begin{array}{l}\text { Near the NW abandoned } \\
\text { Yellow River fault zone, } \\
\text { about } 15 \mathrm{~km} \text { to the west } \\
\text { of Tancheng-Lujiang fault } \\
\text { zone }\end{array}$ & Limestone & 27.6 & 934.8 & $\begin{array}{l}\text { Karst crevice } \\
\text { pressure- } \\
\text { bearing water }\end{array}$ \\
\hline 2 & $\begin{array}{l}\text { Suyu } \\
\text { well } 05\end{array}$ & $\begin{array}{l}\text { Inside the Shuyang depres- } \\
\text { sion, about } 23 \mathrm{~km} \text { to the } \\
\text { east of Tancheng-Lujiang } \\
\text { fault zone }\end{array}$ & Fine sand block & 20.0 & 934.8 & $\begin{array}{l}\text { Crevice } \\
\text { pressure- } \\
\text { bearing water }\end{array}$ \\
\hline 3 & $\begin{array}{l}\text { Jinhu } \\
\text { well } 06\end{array}$ & $\begin{array}{l}\text { Xinglongji height, Li- } \\
\text { uzhuang tectonics, Jinhu } \\
\text { depression }\end{array}$ & Limestone & 10.0 & 2354.7 & $\begin{array}{l}\text { Karst crevice } \\
\text { pressure- } \\
\text { bearing water }\end{array}$ \\
\hline 4 & $\begin{array}{l}\text { Xinghua } \\
\text { well } 08\end{array}$ & $\begin{array}{l}\text { Daiyao tectonics, Qintong } \\
\text { depression }\end{array}$ & Dolomite, limestone & 3.5 & 2680.4 & $\begin{array}{l}\text { Karst crevice } \\
\text { pressure- } \\
\text { bearing water }\end{array}$ \\
\hline 5 & $\begin{array}{l}\text { Nantong } \\
\text { well } 12\end{array}$ & $\begin{array}{l}\text { Inside the EW Huangqiao- } \\
\text { Lvsi fault zone, Tongyang } \\
\text { uplift }\end{array}$ & Diorite & 3.8 & 689.75 & $\begin{array}{l}\text { Karst crevice } \\
\text { pressure- } \\
\text { bearing water }\end{array}$ \\
\hline 6 & $\begin{array}{l}\text { Haimen } \\
\text { well } 14\end{array}$ & $\begin{array}{l}\text { To the south of EW } \\
\text { Huangqiao-Lvsi fault zone, } \\
\text { Tongyang uplift }\end{array}$ & Marble & 3.8 & 463.33 & $\begin{array}{l}\text { Karst crevice } \\
\text { pressure- } \\
\text { bearing water }\end{array}$ \\
\hline 7 & $\begin{array}{l}\text { Jurong } \\
\text { well } 16\end{array}$ & $\begin{array}{l}\text { Near the top of the Qian- } \\
\text { shan uplift, Jurong depres- } \\
\text { sion, to the west of the } \\
\text { Maoshan fault }\end{array}$ & $\begin{array}{l}\text { The interspersion of } \\
\text { magmatic rock and } \\
\text { limestone }\end{array}$ & 20.0 & 889.2 & $\begin{array}{l}\text { Karst crevice } \\
\text { pressure- } \\
\text { bearing water }\end{array}$ \\
\hline 8 & $\begin{array}{l}\text { Dantu } \\
\text { well } 18\end{array}$ & $\begin{array}{l}\text { To the west of Maoshan } \\
\text { east fault of Maoshan fault } \\
\text { zone, to the north of } \\
\text { Maoshan spine of Nanjing- } \\
\text { Zhenjiang reflex arc }\end{array}$ & Limestone & 17.4 & 366.8 & $\begin{array}{l}\text { Karst crevice } \\
\text { pressure- } \\
\text { bearing water }\end{array}$ \\
\hline 9 & $\begin{array}{l}\text { Kunshan } \\
\text { well } 21\end{array}$ & $\begin{array}{l}\text { The uplifted high posi- } \\
\text { tion of Ma'anshan Fault, } \\
\text { Suzhou anticlinorium. }\end{array}$ & Limestone, dolomite & 3.5 & 676.0 & $\begin{array}{l}\text { Karst crevice } \\
\text { pressure- } \\
\text { bearing water }\end{array}$ \\
\hline 10 & $\begin{array}{l}\text { Liyang } \\
\text { well } 22\end{array}$ & $\begin{array}{l}\text { Near the EW anticlinal } \\
\text { axle, Yixing-Liyang moun- } \\
\text { tain area }\end{array}$ & Sandstone & 27.5 & 243.8 & $\begin{array}{l}\text { Crevice } \\
\text { pressure- } \\
\text { bearing water }\end{array}$ \\
\hline
\end{tabular}



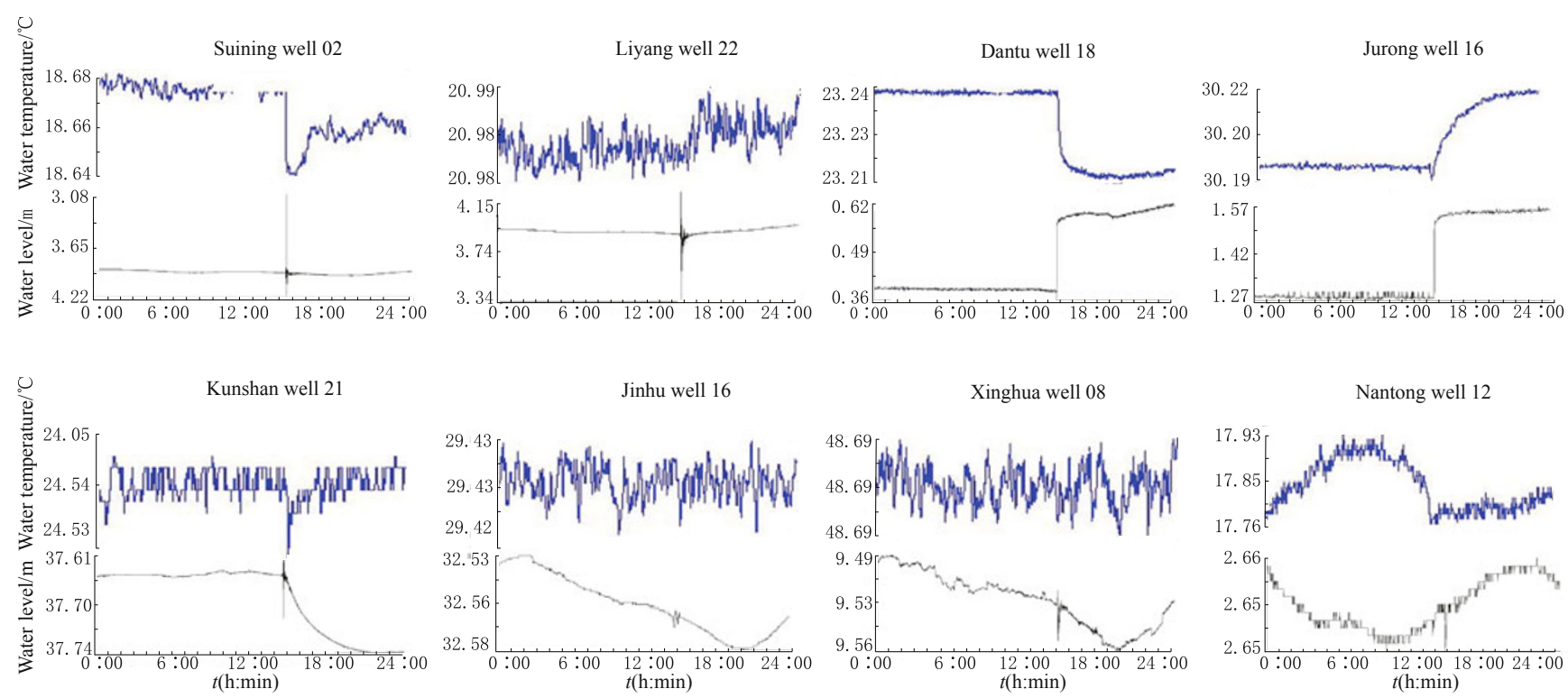

Figure 2 Observations of seismically induced changes in water level and water temperature of an observation well pattern system of Jiangsu Province after the $M_{\mathrm{S}} 8.0$ Wenchuan earthquake.

Table 2 Co-seismic response parameters of water level and water temperature during the $2008 M_{\mathrm{S}} 8.0$ Wenchuan earthquake

\begin{tabular}{llccccc}
\hline $\begin{array}{l}\text { Observation } \\
\text { value }\end{array}$ & $\begin{array}{l}\text { Observed } \\
\text { well holes }\end{array}$ & $\begin{array}{c}\text { Starting time } \\
\text { h:min }\end{array}$ & $\begin{array}{c}\text { Ending time } \\
\text { h:min }\end{array}$ & $\begin{array}{c}\text { Duration } \\
\text { /min }\end{array}$ & $\begin{array}{c}\text { Magnitude of } \\
\text { change/m }\end{array}$ & $\begin{array}{c}\text { Form of } \\
\text { change }\end{array}$ \\
\hline \multirow{5}{*}{ Water level } & Suining well 02 & $14: 32$ & $15: 22$ & 50 & 1.148 & Rise, pulse \\
& Jinhu well 06 & $14: 32$ & $15: 03$ & 31 & 0.009 & Fall, pulse \\
& Xinghua well 08 & $14: 32$ & $15: 03$ & 31 & 0.039 & Rise, pulse \\
& Nantong well 12 & $14: 36$ & $14: 55$ & 19 & 0.006 & Rise, pulse \\
& Jurong well 16 & $14: 34$ & $14: 42$ & 8 & 0.244 & Rise, sudden change \\
& Dantu well 18 & $14: 35$ & $14: 41$ & 6 & 0.209 & Fall, sudden change \\
& Kunshan well 21 & $14: 32$ & $15: 13$ & 41 & 0.113 & Rise, trend \\
& Liyang well 22 & $14: 32$ & $15: 07$ & 35 & 1.086 & Fall; pulse \\
\hline \multirow{5}{*}{ Water temperature } & Suining well 02 & $14: 33$ & $14: 41$ & 8 & 0.032 & Fall, sudden change \\
& Jinhu well 06 & $/$ & $/$ & $/$ & $/$ & $/$ \\
& Xinghua well 08 & $/$ & $/$ & $/$ & $/$ & Fall, sudden change \\
& Nantong well 12 & $14: 36$ & $14: 51$ & 15 & 0.008 & Rise, trend \\
& Jurong well 16 & $14: 37$ & $/$ & $/$ & 0.044 & Fall, sudden change \\
& Dantu well 18 & $14: 38$ & $14: 51$ & 13 & 0.008 & Fall, pulse \\
& Kunshanwell 21 & $14: 32$ & $16: 00$ & 88 & 0.006 & Rise, trend \\
\hline
\end{tabular}

change is slow. For example, in Dantu well 18 and Jurong well 16, a rapid rise occurred six minutes after the earthquake, with a range of about $0.2 \mathrm{~m}$; this was followed by fluctuation around a new base value. By analyzing the long-term observation form, both wells were used for nearly one year before gradually falling to the pre-earthquake water-level observation value. The third type of response is a pulse trend. This is a pulse change, except that it does not fall back to the normal dynamic change, but is instead followed by a steady rise. For example, in Kunshan well 21 a rise-fall pulse occurred four minutes later, and after returning to the normal dynamic value, a slow rising occurred under the subsequent effect of the water seismic wave. About two months later, it gradually restored to the water-level value before the violent Wenchuan earthquake.

The change in water temperature in response to seismic waves is mostly consistent with that of water 
level, but there exist some differences. In general, the water temperature response is not as strong as that of water level. Jinhu well 06 and Xinghua well 08 did not exhibit an obvious change due to co-seismic response. Against the background of a gradual fluctuation, Kunshan well 21 had a concave change of about $0.006{ }^{\circ} \mathrm{C}$. After continuing for 88 minutes, it restored to its normal range. The types of sudden change in watertemperature and water level of Nantong well 12 and Dantu well 18 were similar. Both assumed a fluctuation on a new base value after a rapid fall. About three months later, it restored to the normally observed water temperature. The water temperature of Jurong well 16 and Liyang well 22 did not rise (fall) suddenly after the violent earthquake, but both exhibited a slow rise, with a range of $0.044{ }^{\circ} \mathrm{C}$ and $0.012{ }^{\circ} \mathrm{C}$, respectively. About two months later, it fell slowly again, and gradually restored to the pre-earthquake water-temperature value.

3.2 The seismic change in water level and water temperature after the $M_{\mathrm{S}} 9.0$ Tohoku, Japan earthquake

Figure 3 shows the observation parameters of the fluid well pattern system on the day of the $M_{\mathrm{S}} 9.0$ Tohoku, Japan earthquake. The black curve is the record of the water level in the observation wells, while the blue curve is the record of water temperature from the same wells.
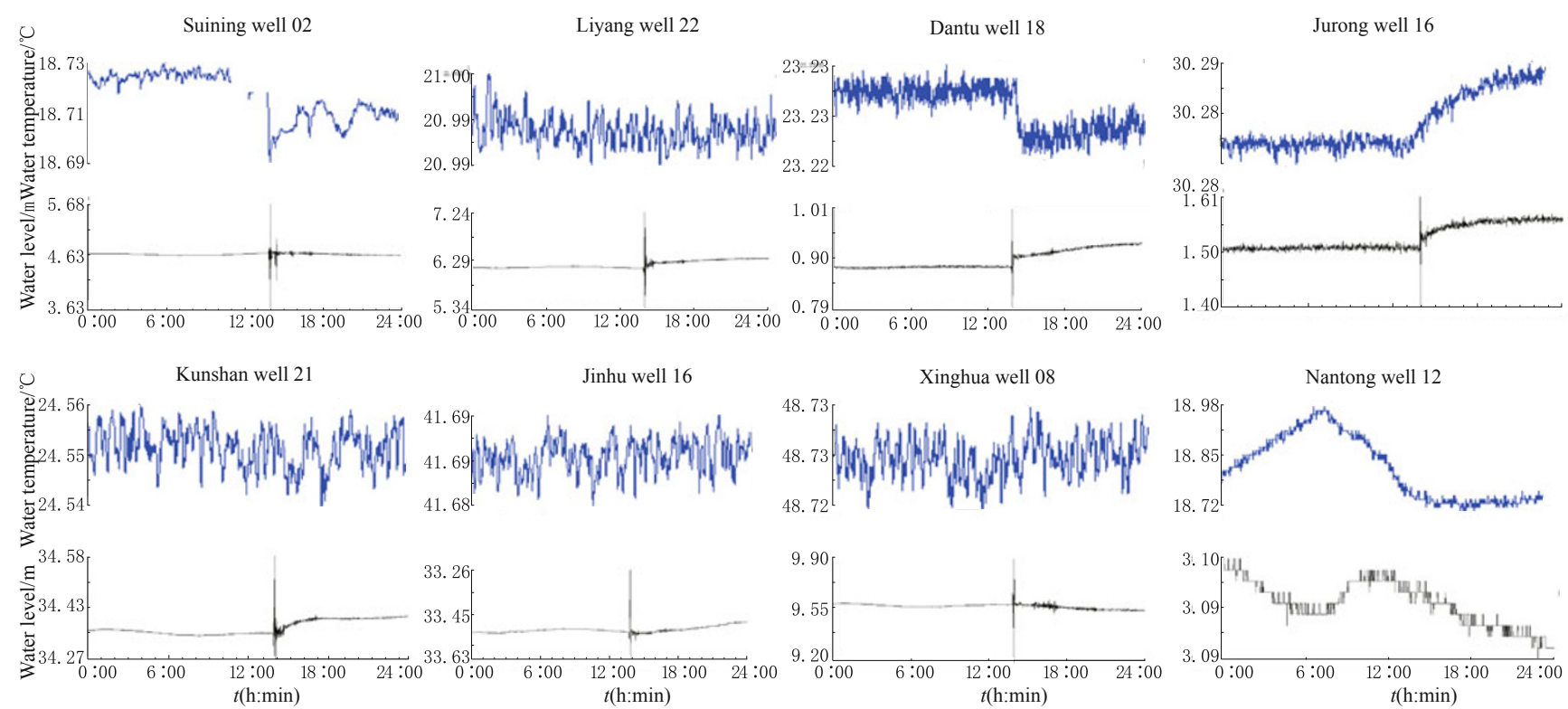

Figure 3 Observations of the seismically induced changes of water level and water temperature of Jiangsu Province well pattern system in response to the $M_{\mathrm{S}} 9.0$ Tohoku, Japan earthquake.

As the $M_{\mathrm{S}} 9.0$ Tohoko, Japan earthquake had a greater magnitude, the water level of seven of the eight observation wells exhibited a pulse of rapid periodic fallperiodic rise (or periodic rise-periodic fall). After continuing for several minutes to half an hour, the observation value was restored to the normal dynamic value. However, Nantong well 12, which showed only a small fluctuation in water level during the $2008 M_{\mathrm{S}} 8.0$ Wenchuan earthquake, showed almost no record of coseismic change during the $2011 M_{\mathrm{S}} 9.0$ earthquake. The water level in six of the seven wells exhibited rapid pulse changes recorded in the co-seismic water wave 4 to 10 minutes after the earthquake. However, the starting time of the co-seismic record of Jinhu well 06 differed. As can be discovered from the co-seismic starting time of Table 3, the water level of this well displayed a rapid fall four minutes after the earthquake. At 13h46min, the principal part of the $M_{\mathrm{S}} 9.0$ Tohoku earthquake occurred. At $13 \mathrm{~h} 48 \mathrm{~min}$ in two minutes after the earthquake, the largest pulse changes occurred, with a range of $0.368 \mathrm{~m}$ (Figure 4), followed by a small fluctuation change lasting for about 20 minutes, and ultimately restoration to the normal background value. In comparison with the Wenchuan earthquake, such phenomenon did not occur in the water level of Jinhu well 06. According to the analysis, this was caused by an error in 
the service clock of the water level observation instrument. As the observation record during the earthquake has already been stored, we cannot accurately rectify the time now. Even though the topic of this study does not require precise timing, the time error of several minutes is notable for the accuracy of portent data and the subsequent applications.

Table 3 Co-seismic response parameters of water level and water temperature during $M_{\mathrm{S}} 9.0$ Tohoku, Japan earthquake

\begin{tabular}{|c|c|c|c|c|c|c|}
\hline $\begin{array}{l}\text { Observation } \\
\text { value }\end{array}$ & $\begin{array}{l}\text { Observed } \\
\text { well holes }\end{array}$ & $\begin{array}{c}\text { Starting time } \\
\text { h:min }\end{array}$ & $\begin{array}{l}\text { Ending time } \\
\text { h:min }\end{array}$ & $\begin{array}{l}\text { Duration } \\
\text { /min }\end{array}$ & $\begin{array}{c}\text { Magnitude of } \\
\text { change/m }\end{array}$ & $\begin{array}{l}\text { Form of } \\
\text { change }\end{array}$ \\
\hline \multirow{8}{*}{ Water level } & Suining well 02 & $13: 51$ & $14: 16$ & 25 & 2.003 & Fall, pulse \\
\hline & Jinhu well 06 & $13: 42$ & $14: 02$ & 20 & 0.368 & Fall, pulse \\
\hline & Xinghua well 08 & $13: 50$ & $14: 05$ & 15 & 0.702 & Fall, pulse \\
\hline & Nantong well 12 & / & / & / & / & / \\
\hline & Jurong well 16 & $13: 56$ & $14: 13$ & 17 & 0.216 & Rise, pulse \\
\hline & Dantu well 18 & $13: 52$ & $14: 03$ & 11 & 0.228 & Fall, pulse \\
\hline & Kunshan well 21 & $13: 52$ & $14: 17$ & 25 & 0.304 & Fall, pulse \\
\hline & Liyang well 22 & $13: 51$ & $14: 16$ & 25 & 1.905 & Fall, pulse \\
\hline \multirow{8}{*}{ Water temperature } & Suining well 02 & $13: 50$ & $14: 18$ & 28 & 0.035 & Fall, sudden change \\
\hline & Jinhu well 06 & / & / & / & / & / \\
\hline & Xinghua well 08 & / & / & / & / & / \\
\hline & Nantong well 12 & / & / & / & / & / \\
\hline & Jurong well 16 & $13: 56$ & / & / & 0.011 & Rise, trend \\
\hline & Dantu well 18 & $13: 58$ & $14: 33$ & 35 & 0.006 & Fall, sudden change \\
\hline & Kunshan well 21 & / & / & / & / & / \\
\hline & Liyang well 22 & / & / & / & / & / \\
\hline
\end{tabular}

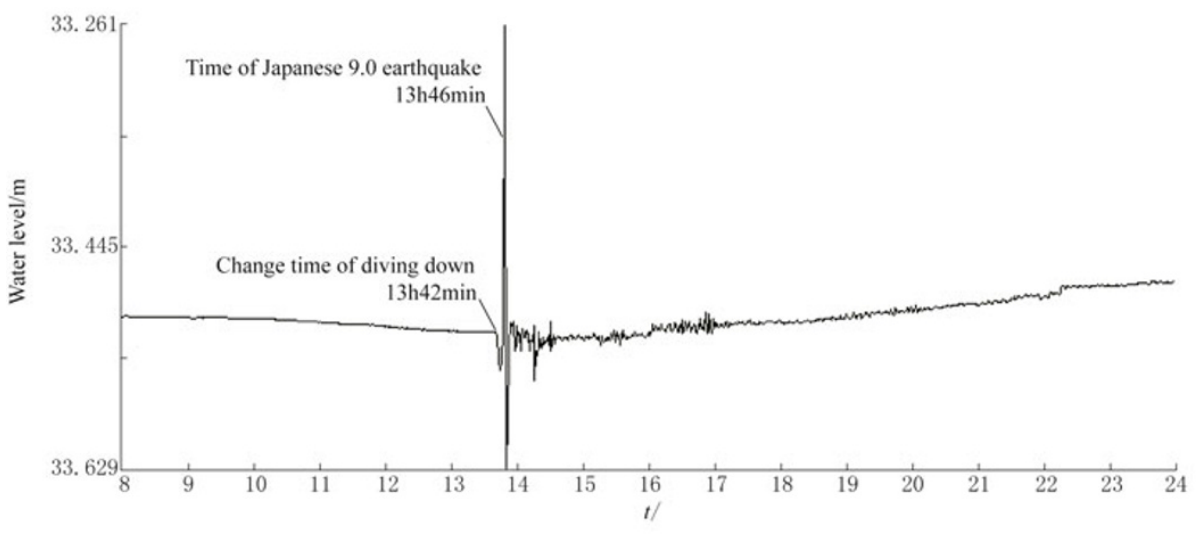

Figure 4 The water level of Jinhu well 06, hour 08 to 24 on March 11, 2011.

Although the 2011 Tohoku, Japan earthquake had a greater magnitude than the 2008 Wenchuan, China earthquake, it had a smaller seismic influence on the water temperature of the regional well pattern system of Jiangsu Province. Only Suining well 02, Dantu well 18 and Jurong well 16 showed seismic responses, and the seismic change in water temperature of Suining well 02 was similar to that of the Wenchuan earthquake, assuming a concave change, and a similar range of change, decreasing $0.035^{\circ} \mathrm{C}$ and $0.032^{\circ} \mathrm{C}$, respectively. The for- $\mathrm{m}$ of the co-seismic change of water temperature of Jurong well 16 and Dantu well 18 were also similar to that of the Wenchuan earthquake, only with a small range of fall (rise), $0.011^{\circ} \mathrm{C}$ and $0.006^{\circ} \mathrm{C}$, respectively, with a more gradual trend. Figure 5 is the graph of hourly water temperature values of the three wells from March 11 (when the earthquake occurred) to three months after the earthquake. As can be seen from the figure, the post-earthquake effect on water temperature of three wells is completely different. Suining well 02 continued 
to change steadily to a new base temperature immediately after a rapid and sudden fall. Jurong well 16 maintained a steady change before the earthquake but rose suddenly during the earthquake, and began to fal1 after the high value for one day; the rate of fall was alternatingly high and low, and became stable in June 2011. After that, at $30.255^{\circ} \mathrm{C}$ a new base-value line fluctuation change occurred, declining $0.024^{\circ} \mathrm{C}$ compared to $30.279^{\circ} \mathrm{C}$, the base value before earthquake. Dantu well 18 developed a large background fluctuation in water temperature. Although the co-seismic effect followed a concave change, the range of change was small, only $0.006^{\circ} \mathrm{C}$. After the earthquake, the water temperature rose slightly, and returned to normal about one month later.

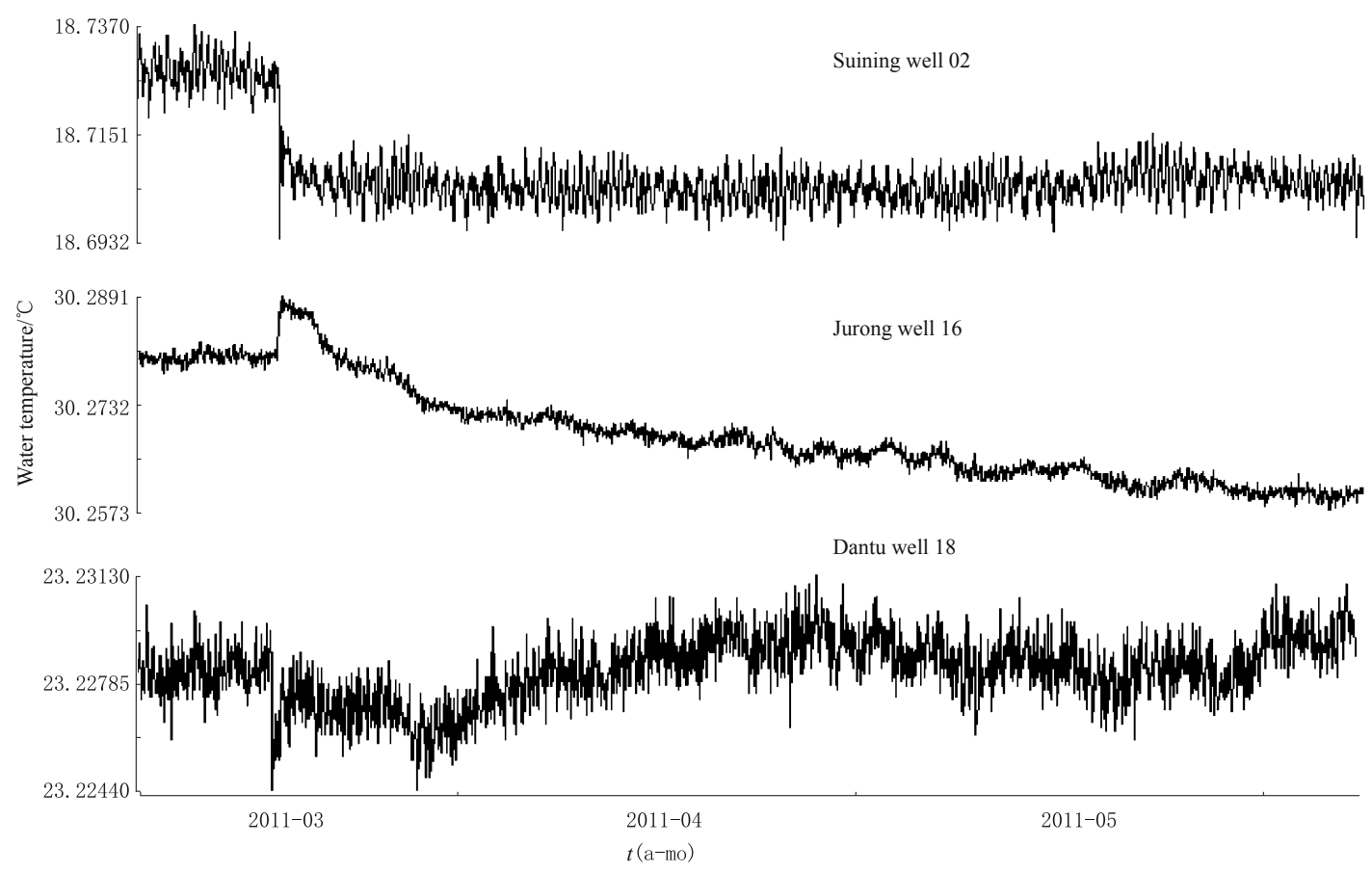

Figure 5 Water-temperature values for Suining well 02, Jurong well 16 and Dantu well 18 for every hour after the $M_{\mathrm{S}} 9.0$ Tohoku, Japan earthquake.

3.3 Comparative analysis of the co-seismic response features of the two earthquakes

\subsubsection{Response relationship between changes} in water level / water temperature and earthquake magnitude / distance

Matsumoto (1992), Roeloffs (1998), and Yang etal., (2005) have researched the relationship between the degree of change in water level and earthquake magnitude/distance to the Japanese Haibara well, the American Californian Parkfield BV well, and the Yunnan Simao well, respectively. The research findings show that the post-earthquake change in well water level, the earthquake magnitude, and the well-to-earthquake distance follow the relationship:

$$
\log _{10} \Delta h=b_{1} M+b_{2} \log _{10} D+\alpha,
$$

where, $\Delta h$ indicates the degree of change in water level measured in the units of $\mathrm{cm}$; $M$ indicates the earth- quake magnitude; $\alpha, b_{1}, b_{2}$ are constants; and $D$ is the well-to-earthquake distance.

We carried out regression calculations of the ten wells in Jiangsu Province according to the statistical values in Tables 2 and 3, obtaining

$$
\log _{10} \Delta h=0.74 M-1.16 \log _{10} D-0.54 \text {. }
$$

The degree of change in water level in response to a second strong earthquake in the region basically follows relation (2). This can be seen especially in Suining well 02 and Liyang well 22, which are subject to changes of large-scale pulse rises (or drops) in water level $(\Delta h>100$ $\mathrm{cm})$.

Then we calculate the correlation coefficient of the eight wells. In the Wenchuan earthquake, the correlation coefficient of the actual water level and the theoretical water level is 0.771 . In the Japan earthquake, the corre- 
lation coefficient is 0.726 . This shows that the relation (2) reflect the relationship between $\Delta h, D$ and $M$.

By further analyzing the change in water level and water temperature, we find that, the greater effect an earthquake has on water level, the greater the change in temperature will be (Figure 6). When the degree of change in water level is assumed to be the independent variable $x$ (in units of $m$ ), and the degree of change in temperature is assumed to be the dependent variable $y$ (in units of ${ }^{\circ} \mathrm{C}$ ), then they meet the power function:

$$
y=0.099 x^{-05031} \text {. }
$$

According to Figure 6, in the case of a second strong earthquake, most stations are subject to changes in water level of $10 \mathrm{~cm}<\Delta h<50 \mathrm{~cm}$, and in water temperature of within $0.005^{\circ} \mathrm{C}$. When the change in water level is more than $1 \mathrm{~m}$, the temperature will change greatly. Obviously, in the co-seismic response of a fluid, the temperature change corresponds well to the oscillation in water level.

\subsubsection{Contrast analysis of different observation items of the same well}

All ten wells in Jiangsu Province were observed at the still water level (refer to Table 4 for the statistic results of the seismic responses of the ten wells during the two earthquakes). The observations in Jinhu well 06 and Xinghua well 08 were of deep water temperature, with depths of $400 \mathrm{~m}$ and $800 \mathrm{~m}$ from the fixed benchmark surface of the well mouth, respectively. The vertical distance of the probe launched from the fixed benchmark surface of the well mouth to the well tube was $30 \mathrm{~m}$ to $50 \mathrm{~m}$, respectively. The other eight wells were medium-level water temperature, with a depth of $200 \mathrm{~m}$ from the well mouth.

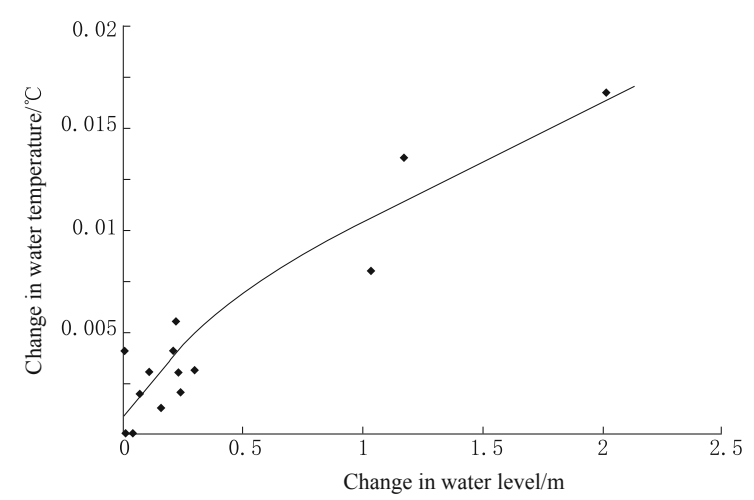

Figure 6 Relationship between change in water level and change in water temperature due to coseismic response.

Table 4 Statistics of the digitized seismic response abilities of water level and water temperature in Jiangsu Province

\begin{tabular}{|c|c|c|c|c|c|}
\hline \multirow{2}{*}{ Serial No. } & \multirow{2}{*}{ Well No. } & \multicolumn{2}{|c|}{$2008 M_{\mathrm{S}} 8.0$ Wenchuan earthquake } & \multicolumn{2}{|c|}{$2011 M_{\mathrm{S}} 9.0$ Tohoku earthquake } \\
\hline & & Water level & Water temperature & Water level & Water temperature \\
\hline 1 & Suining well 02 & $\bullet$ & $\bullet$ & $\bullet$ & $\bullet$ \\
\hline 2 & Suyu well 05 & $\circ$ & $\circ$ & $\circ$ & $\circ$ \\
\hline 3 & Jinhu well 06 & $\bullet$ & $\circ$ & $\bullet$ & $\circ$ \\
\hline 4 & Xinghua well 08 & $\circ$ & $\circ$ & $\circ$ & $\circ$ \\
\hline 5 & Nantong well 12 & $\bullet$ & $\bullet$ & $\circ$ & $\circ$ \\
\hline 6 & Haimen well 14 & $\circ$ & $\circ$ & $\circ$ & $\circ$ \\
\hline 7 & Jurong well 16 & $\bullet$ & $\bullet$ & $\bullet$ & $\bullet$ \\
\hline 8 & Dantu well 18 & $\bullet$ & $\bullet$ & $\bullet$ & $\bullet$ \\
\hline 9 & Kunshan well 21 & $\bullet$ & $\bullet$ & $\bullet$ & 0 \\
\hline 10 & Liyang well 22 & $\bullet$ & $\bullet$ & $\bullet$ & o \\
\hline
\end{tabular}

Note: The solid circle stands for seismic response, and the open circle for no seismic response.

As can be seen from Table 4, the water level and water temperature of Suyu well 05 and Haimen well 14 had no co-seismic response to these two violent earthquakes, accounting for $20 \%$ of all observation wells. During the Wenchuan earthquake, the water level of eight wells recorded water seismic waves, accounting for $80 \%$ of all observation wells, six wells recorded watertemperature changes, accounting for $60 \%$. During the
Japan earthquake, the water level of seven wells recorded water seismic waves, accounting for $70 \%$ of all observation wells, and only three wells recorded watertemperature changes, accounting for 30\%. During the two earthquakes, the water level and water temperature of only three wells (Suining well 02; Jurong well 16; Dantu well 18) recorded co-seismic changes at the same time. The co-seismic response of water level fo- 
cused on the pulse type change, with the range of change greater than the co-seismic change of water temperature. Water temperature followed a trend-type change, with a greater duration in co-seimic response and postearthquake adjustment time than that of water level.

The earthquake-recoding capacity of water level and water temperature is closely related to their respective change mechanisms. The change of water level is mainly influenced by the interstitial pressure and water-flow velocity in the water-bearing stratum. If the pressure-bearing and closure of the water-bearing stratum of a well is good, then even a very weak change of the stress-strain can be demonstrated in the water level change. The water temperature change is the result of the energy exchange between underground water and its surrounding media. The exchange of energy is not subject to the limitation of the storage space of underground water. In addition to being subject to the influence of the water flow velocity, the change of water temperature is also subject to the control of such factors as the path of water flow, the heat-transmission performance of surrounding rock media, and the depth of the water-temperature probesinthe observation wells. Therefore, the different change mechanisms of water level and water temperature result in the major difference in the response ability and response image of the same well to the same earthquake.

\subsubsection{Comparative analysis of the same obser-} vation parameter in different earthquakes

As can be seen from Table 4, for both water level and water temperature observations, the number of well holes of co-seismic response recorded during Wenchuan earthquake is larger than that of well holes recorded during the Tohoku earthquake. The epicenter of the Wenchuan earthquake is about 1300 to $1500 \mathrm{~km}$ away from the Jiangsu Province, while the epicenter of the Tohoku earthquake is about $2300 \mathrm{~km}$ to $2500 \mathrm{~km}$ away. Although the magnitude of the Tohoku earthquake was greater, the increased distance made the tectonic elements, type of underground water and the water-transmission capacity of water-bearing stratum between them more complicated and diversified, and led to the difference in seismically induced periodic-change range of water level and water temperature of various wells, the restoration time of periodic change, and the after effect of seismic responses.

We can clarify that the degree of water-level seismic response is closely related to the magnitude of distant earthquakes. The greater the magnitude, the higher the response. By comparing Figure 2 with Figure
3 , we see that the water-level co-seismic change during the 2011 Tohoku, Japan earthquake was characterized by a drastic pulse followed by rapid restoration to the background value. In contrast, the water level coseismic change during the Wenchuan earthquake was much more gradual (e.g. Jinhu well 06, Xinghua well 08, Natong well 12 and Jurong well 16). However, water temperature does not follow this law (e.g. Liyang well 21 and Kunshan well 22). The Tohoku earthquake had no co-seismic abnormalities. The co-seismic change forms and ranges of water temperature of other wells were also on the small side. Because the temperature change usually depends on such factors as the rock water permeability and temperature gradient, the temperature response lag time of probes and the temperature change is far more complicated.

\subsubsection{Adjacent well holes in the same fault zone have completely different responses to disastrous earthquakes}

In the ten observation wells for which the two observation items (water level and temperature) were set at the same time during the two earthquakes, water level and water temperature of three wells recorded coseismic response. During both earthquakes, two wells had no co-seismic change of either water level or water temperature. This proves that the monitoring ability of different wells in the region can have large differences.

The adjacent well holes on the same fault zone have completely different response strengths to violent earthquakes. There are two groups of wells that are most typical of this: Suining well 02 and Suyu well 05; Nantong well 12 and Haimen well 14. Suining well 02 and Suyu well 05 are located on both sides of the TanchengLujiang fault zone, and the distance between the two wells is about $80 \mathrm{~km}$. The basic conditions of these two wells, including the lithology, well-formation depth and the type of underground water, were very similar, but they responded very differently to distant violent earthquakes. No seismic change occurred in the water level or the water temperature of Suyu well 05 during the two earthquakes. The same occurred at Nantong well 12 and Haimen well 14. Both wells are located in the E-W Huangqiao-Lüsi fault zone of Tongyang uplift, $20 \mathrm{~km}$ away from each other. However, no seismic change occurred in Haimen well 14 during these two great earthquakes. This phenomenon all the more proves that the monitoring efficiency of this well is perhaps inadequate.

In terms of the whole region, subject to the influence of such factor as the thick covering layer or the type of underground water, several wells in central Jiangsu 
had a low overall sensitivity in their response to distant and violent earthquakes. In contrast, the four well$\mathrm{s}$ in southern Jiangsu (including wells 16, 18, 21 and 22) had a high level of monitoring in such parameters as the response time, periodic-change range and subsequent change.

\section{Discussion and conclusions}

Based on the observation of water level and water temperature of the ten wells in a digitized underground fluid observation well pattern system in Jiangsu Province, this thesis discusses the seismic change characteristics and response of water level and water temperature to the $2008 M_{\mathrm{S}} 8.0$ Wenchuan earthquake and the $2011 M_{\mathrm{S}} 9.0$ Tohoku earthquake, and draws the following preliminary conclusions.

As indicated by the seismic response data of the ten wells in Jiangsu Province, the earthquake-recording ability of water-level at a series of observation points in this region was notably stronger than that of water temperature. The seismic response of the water level at most wells followed a consistent law describing its change, and was closely related to the earthquake magnitude. The greater the magnitude, the stronger the response, and the more instantaneous its influence upon the stress state of well regions. Pulse oscillation prevailed, and restored to its original state soon after the earthquake. Water temperature and water level had different response mechanisms, so they had different response degrees and forms, and there also existed a major difference between the changes in water temperature of different well holes, which was mostly manifested as a slow restorative change. That is to say, after water level stopped oscillating, the crosswise water-power action of the water body of water-bearing stratum and well water was not stopped. There still existed a relatively slow process of heat convection in the water body of the water-bearing stratum, which perhaps slowed down the restorative velocity of the well water temperature.

Tectonic elements had a clear effect on well hole response. In central Jiangsu and northern Jiangsu, only Suining well 02 had a good reflection of water level and water temperature to the two great earthquakes, and most of the well holes had an unclear reaction to the micro-dynamic change of water level and water temperature caused by distant earthquakes. Good seismic response changes were recorded during these two earthquakes in the water level and water temperature of the well holes in southern Jiangsu. The difference be- tween the strong and weak earthquake-recording ability in southern and northern Jiangsu, respectively, may have been caused by the different geological structures in which these observation wells are located. The tectonic characteristics of the thicker loess covering layer in central Jiangsu made it weaker than the hilly land in southern Jiangsu in capturing the micro-changes of stress-strain states. The more complicated geological structure in southern Jiangsu was more favorable to the change of the state of underground water after a minor disturbance.

The error caused by the advance of the co-seismic response time and the occurrence time of the Tohoku earthquake to the water level of Jinhu well 06 had a major effect on the accuracy of the portent observation data and the further application of observation data. Strengthening the checks in the time service system of portent observation is one of the problems that we must pay attention to during our monitoring work.

Acknowledgements The authors would like to express their sincere gratitude to the two anonymous reviewers for their valuable comments on this paper. This study is finacially supported by the Scientific and Technological Support Project of Jiangsu Province (No. BS2007084) and Seismic Technology Spark Project (No. XH12020).

\section{References}

Blanchard F B and Byerly (1935). A study of a well gauge as a seismograph. Bull Seismol Soc Am 25(1): 313-321.

Chen D Q and Liu Y W (2006). Summaries of the research of the co-seismic response of well-aquifer systems to seismic waves in China. Recent Developments in World Seismology 7: 27-31 (in Chinese with English abstract).

Che Y T (1990). Studies on the conditions affecting the sensitivity of observational well related to earthquake precursors. Earthquake in China 6(4): 67-72 (in Chinese with English abstract).

Fu H, Wu C D, Liu Q and Wang S Q (2007). Abnormal water level records caused by Indonesia large earthquakes in Yunnan and its significance. Seismology and Geology 29(4): 873-882 (in Chinese with English abstract).

Gu S Y, Li Z X and Zhang H (2010). Analysis of the characteristics of co-seismic records of five wells' water level in Hainan area in the M8.0 Wenchuan earthquake event. J Seism Res 33(1): 36-43 (in Chinese with English abstract).

Gao X Q, Chen H J and Yang Y L (2006). Coseismal effect of Indonesia M8.7 earthquake on Dec. 26, 2004 in Xinjiang region. Seismological and Geomagnetic Observation and Research 27(3): 40-46 (in Chinesewith Englishabstract). 
Huang F Q, Chi G C, Xu G M and Jian C L (2000). Research on the response anomalies of subsurface fluid in mainland monitoring network to the Nantou earthquake with M7.6. Earthquake 20(Suppl.): 119-125 (in Chinese with English abstract).

Liao L S, Wang M L and Wu S Z (2009). Study on co-seismic effects of water level as observed by Fujian well network and its implication to earthquake prediction. Acta Seismologica Sinica 31(4): 432-441 (in Chinese with English abstract).

Liu W Z (2003). Behaviors of subsurface fluid and their responsibility to seismic event in three-gorge observation well network. Seismology and Geology 25(4): 632-639 (in Chinese with English abstract).

Matsumoto N (1992). Regression analysis for anomalous changes of ground water level due to eathquake. Geophys Res Lett 19(12): 1 193-1 199.

Rexin E E, Oliver J and Prentiss D (1962). Seismicallyinduced fluctuation of the water level in the Nunn-Bush Well in Milwaukee. Bull Seismol Soc Am 52(1): 17-25.

Roeloffs E A (1998). Persistent water level changes in a well near Parkfield California, due to local and distant earth- quakes. J Geophys Res 103(B1): 869-889.

Yin B J, Ma L and Chen H Z (2009). Characteristics of co-seismic water level change in Tangshan well induced by $M 8.0$ Wenchuan earthquake and its large aftershocks. Acta Seismologica Sinica 31(2): 195-204 (in Chinese with English abstract).

Yang Z Z, Deng Z H, Zhao Y X and Zhu P Y (2005). Preliminary study on co-seismic steps of water-level in Dazhal well. Simao City, Yunnan Province. Acta Seismologica Sinica 27(5): 569-574 (in Chinese with English abstract).

Yang Z Z, Deng Z H and Tao J L (2007). Co-seismic effects of water temperature based on digital observation from Tayuan well. Beijing. Acta Seismologica Sinica 29(2): 203-213 (in Chinese with English abstract).

Zhang Y X, Shi Y U and Zhang G M (1991). Model studies on relationship between underflow and its temperature and discussions about mechanism of groundwater temperature precursor. Earthquake in China 7(3): 88-94 (in Chinese with English abstract).

Zhang Z D, Chi Z L and Chen H M (2000). Vibration of water level in well and earthquake wave. $J$ of Seism Res 23(4): 418-425(in Chinese with English abstract). 